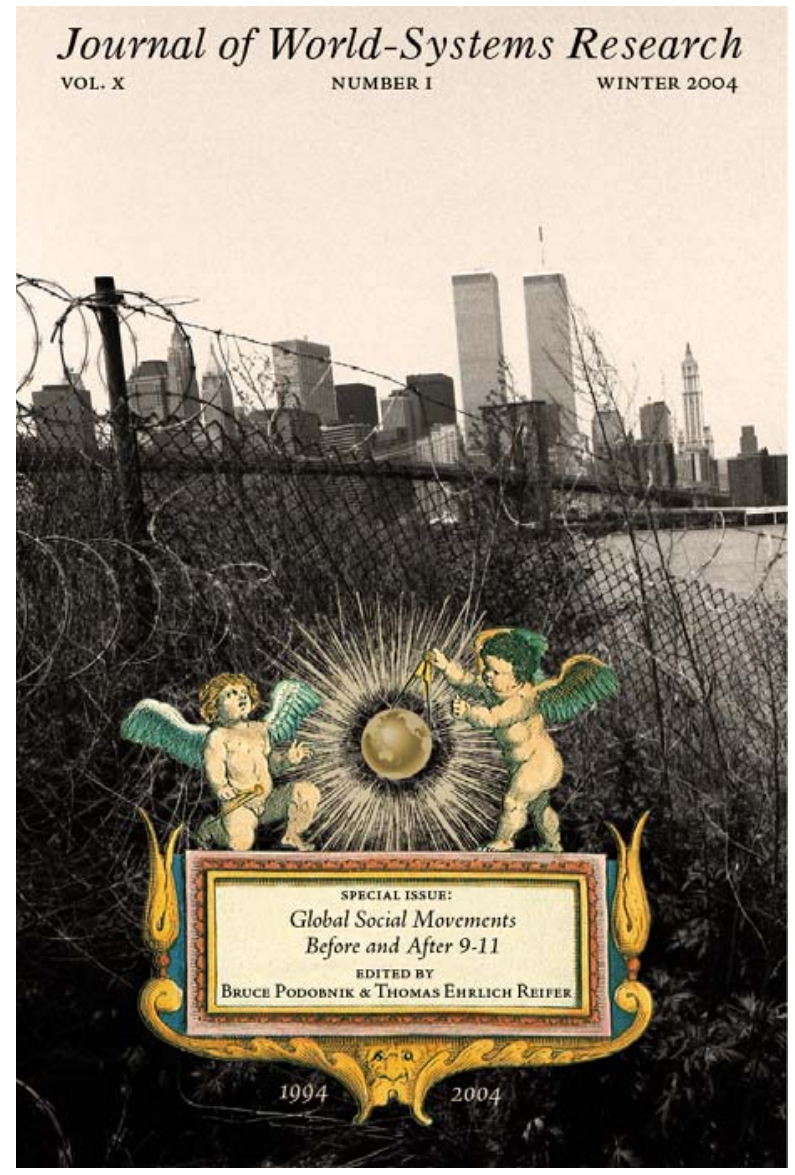

ABSTRACT

The rise of the protest movement agains neoliberal globalization represents one of the most significant illustrations of social conflict and contentious political behavior of the past several decades. This paper contends that cen tral to the movement's rise and evolution has been the active mobilization of meanings $o$ interpretations critical of neoliberal policies and institutions. In effect, the so-called "antiglobalization movement" has benefited particularly from a transnationally-shared diagnosis, which implicates neoliberalism for a host of global social ills. However, civil society activ ists, especially after the Seattle World Trade Organization protests in 1999, have had a dif-

\section{Framing Collective Action Against Neoliberalism: The Case of the "Anti- Globalization" Movement}

Jeffrey M. Ayres

\section{INTRODUCTION}

The rise of the so-called "anti-globalization movement" represents one of the most significant illustrations of social conflict and contentious political behavior of the past several decades. The numerous boisterous and well-attended protest events against neoliberal globalization at the turn of the century, moreover, seemed to provide evidence of the rise of an incipient transnational movement, as from Seattle, to Chiang Mai, to Prague, to Quebec City and finally Genoa, domestic and internationally-represented protests developed solidarities, stirred public debate and attracted larger crowds committed to challenging neoliberal policies and institutions. The transnational character of this movement attracted particular attention, and its emergence coincided with a remarkable and increasingly well-documented upsurge in transnational civic activity around a host of global issues (Smith, Pagnucco and Chatfield 1997, Della Porta, Kriesi and Rucht 1999; Tarrow 200I; Khagram, Riker and Sikkink 2002; Smith and Johnston 2002), while sparking a mini-publishing industry of "how-to" manuals for budding street activists (Danaher and Burbach 2000; Welton and Wolf 200I; Prokosch and Raymond 2002).

One means of understanding the recent trajectory of this protest movement is to appreciate that its dynamics have been shaped by an underlying and quite ferocious contest over people's interpretations and understandings of the supposed benefits of neoliberal economic policies. How people interpret and frame

ficult time generating agreed upon strategic responses to neoliberal policies. In particular, the political environment for frame dissemination has become a much more contested one in the aftermath of the September 11 terrorist attacks on the United States, as regional and tactical differences within the protest movement have become much more apparent. The difficult experiences of civil society groups committed to sustaining protest against neoliberal globalization are not unusual, but consistent with the history of other protest movements. These movements similarly matured and positioned themselves as genuine forces for substantial political and social change.
Jeffrey M. Ayres

Department of Political Science

Saint Michael's College

Box 362, 1 Winooski Park

Colchester, Vermont 05439

jayres@smcvt.edu

http://academics.smcvt.edu/jayres/

JOURNAL OF WORLD-SYSTEMS RESEARCH, X, I, WINTER 2004, II-34 Special Issue: Global Social Movements Before and After 9-II

http://jwsr.ucr.edu/

ISSN $1076-156 \mathrm{X}$

(C) 2004 Jeffrey M. Ayres 
understandings of current economic globalization processes-and how these conceptual framings coalesce to structure global protest-is a process at least as important as how political-economic changes associated with globalization have provoked collective action. ${ }^{1}$ In fact, part of the framing contest surrounding the globalization debate has centered on the label "anti-globalization;" what we have really been witnessing over the past several years is a maturing of a protest movement against contemporary neoliberal globalization processes. Moreover, critical to this contentious mobilization has been the crystallization of a broadly interpretive, increasingly transnationally-shared diagnostic frame that attributes a variety of social ills to the past $15-20$ year span of neoliberal ascendancy.

That the world's economy has been undergoing a neoliberal transformation over the past twenty years is hardly in dispute (MacEwan 1999; Tabb 2003). Responding to the global economic slowdown as well as increased international competitiveness for markets, which characterized the I970s, political and business leaders in several key Northern developed states undertook dramatic politicaleconomic reforms designed to channel the globalization of the world's economy in a so-called neoliberal direction. Proponents of neoliberalism, perhaps most notably the Reagan and Thatcher governments of the 1980s, thus pushed for more liberalized trade and investment, tax cuts and concurrent cuts in public spending on social services, deregulation and the privatization of state-owned industries or services. Notably, such a policy direction was at odds with the initial legitimizing basis for the post-World War Two Bretton Woods international economic management system, in which government regulation, social welfare systems and full employment policies were considered an acceptable compliment to essentially still market-based fundamentals (Korten 1996).

However, the break with the Bretton Woods regime in the I970s and the resulting neoliberal turn in the global economy played an important role in shaping the incidences of national, regional and at times apparently transnational protest, which erupted in the I990s to challenge the neoliberal globalization paradigm. Rising criticism and mounting public demonstrations directed at neoliberal policies and institutions had been occurring globally for some time, but gained particular attention after the 1999 World Trade Organization (WTO) protests in Seattle, raising the specter of a budding legitimacy crisis within the

1. The amount of research documenting the role played by political opportunities and mobilizing structures in social movement development is voluminous; a good beginning approach for sampling this literature would be to consult McAdam, McCarthy and Zald (1996) and Tarrow (1998) for excellent synthetic overviews. neoliberal paradigm (Useem 2002; Finnegan 2003). Proponents of neoliberal policies insisted that there remained few alternatives to neoliberal globalization, while the protestors asserted that the globalization of the world's economy in fact need not inevitably follow a neoliberal template. Rather, many varied proposals for what was argued to be a more socially, economically and ecologically equitable globalization process began to emerge and to be debated. ${ }^{2}$

This paper examines the importance of the mobilization of contentious beliefs and interpretations critical of neoliberal globalization. The record of neoliberalism has given activists a wealth of shared experiences from which to fashion a meaningful and increasingly transnationally-shared understanding of the perceived negative effects of such policies. The discussion herein focuses broadly on the challenges facing civil society activists as they have tried to fashion and sustain such a transnational consensus that both attributes blame and develops strategies of action against neoliberal policy initiatives. Yet, the events of September II, 20oI have clearly muddied the potential trajectory of this protest movement: while some activists have maintained that the mobilization potential of the movement has been little changed by the fallout from the terrorist attacks on the United States, others in the media and various political establishments have been quick to write off the movement's potential. Clearly, the protest movement after September II has evolved within a more constrained political environment, with activists facing a markedly resilient state, and a resurgent neoliberal agenda (Ayres and Tarrow 2002). At the same time, the events of September II and its aftermath have had an unintended effect of illustrating the durable character of the protest movement, which has surprisingly wide geographic reach.

\section{COLLECTIVE ACTION FRAMES AGAINST NEOLIBERAL GLOBALIZATION}

The concept of framing processes is analytically useful for highlighting how the development and spread of mobilizing ideas are integral to social movement dynamics (Snow et al. 1986; Snow and Benford 1988). For movement activists, framing is "meaning work": an active and contentious process where actors are engaged in producing and disseminating meanings that differ from and may in fact challenge existing socio-political conditions (Benford and Snow 2000). As such, when movement participants "frame" a particular social condition, "they frame, or assign meaning to and interpret events and conditions in ways that are

2. For just a few examples see Clark (2003), Henderson (1999), and Foster and Anand (1999). 
intended to mobilize potential adherents and constituencies, to garner bystander support and to demobilize antagonists" (Snow and Benford 1988: 198). Framing processes thus will be seen to provide a useful conceptual guide for understanding the ongoing struggle to produce and disseminate mobilizing ideas critical of neoliberal globalization.

So-called collective action frames result from this meaning production and serve several crucial functions for movements. Collective action frames are "constructed as movement adherents negotiate a shared understanding of some problematic condition or situation they define as in need of change, make attributions regarding who or what to blame, articulate an alternative set of arrangements and urge others to act in concert to affect change" (Benford and Snow 2000: 613). In other words, collective action frames provide diagnostic attribution, which is concerned with problem identification, and prognostic attribution, which is concerned with problem resolution (Snow and Benford 1992). So-called "master frames" serve similar functions to movement specific collective action frames. However, master frames provide broader interpretive paradigms for multiple movements, shaping the outlook of activists and movements. When faced with what are interpreted as unjust social conditions, activists, then, develop movement specific, and sometimes master collective action frames, to highlight the unjust character of events or conditions which are no longer tolerable and are now framed as undefendable (Ibid: 137). Such frames then provide "legitimizing accounts" (McAdam, McCarthy and Zald 1988: 713) shaping and sustaining mobilization campaigns.

Activists by the late r 990 os successfully developed a contentious, increasingly transnationally-accepted master collective action frame to challenge the prevailing neoliberal orthodoxy as it existed in such institutions as the WTO, the International Monetary Fund (IMF) and regional trade agreements such as the North American Free Trade Agreement (NAFTA). The construction of such an anti-neoliberal globalization collective action frame involved an especially long, contentious and difficult process, as movement activists faced two especially daunting challenges: a powerful and wealthy set of interests in those states, corporations and other social actors supportive of neoliberal policies; and the diversity of different regions, states, languages, cultures and popular experiences affected by neoliberal globalization. For example, where Canadian social activists in the mid-I980s may have crafted one of the earliest collective action frames in the developed North against neoliberalism in their protest movement against the Canada-U.S. Free Trade Agreement (CUSFTA), the experiences of these Canadians differed considerably from the socially disruptive effects of the IMF's structural adjustment programs, which had encouraged numerous incidents of riots, strikes and other acts of acute collective action across states in the develop- ing South. Thus, while various movement and region-specific collective action frames were emerging throughout the I980s and early I990s in different parts of the world, it would require the development of more inclusive master frame to bind disparate actors into a protest movement against neoliberalism that increasingly had achieved international scope.

\section{Diagnostic Framingः Identifying Neoliberalism as "the Problem"}

Again, by the early-to-mid-I99os, many regions of the world had become settings for contentious political debates and social conflicts between opponents and proponents of neoliberal globalization policies. Across these disparate areas, activists were increasingly linking a variety of social, political and economic problems with some of the major developments in the global political economy. In particular, activists labeled international institutions and regimes associated with the advancement of neoliberal policies, as those actors responsible for some of the economic dislocations and political conflicts of recent years. Thus a process of diagnostic framing was unfolding, serving to motivate individuals through movement specific collective action frames that attacked tenets of neoliberalism.

For example, across Western Europe, the first salvos in what would ultimately evolve into what have become the tens-of-thousands strong European Union (EU) summit protests in recent years emerged with opposition to the European Monetary Union proposals implicit in the Maastricht Treaty. Some states, such as Denmark, outright rejected the treaty (Geyer and Ayres 1995), while others witnessed widespread popular upheaval against the accord's perceived mandate for fiscal austerity and social cutbacks. The massive and disruptive French general strike against the then Juppé government's economic proposals in the winter of 1995 was but the most dramatic example of this public discord (Rodrik 1997; Bourdieau 1998; Ancelovici 2002). More widespread and mainstream concerns about an emerging Maastricht-induced European democratic deficit linked constraints bearing down on the sovereign policy-making capacities of EU-member governments, and fed growing popular perceptions of an aloof clique of European business and political elite more concerned with maximizing continental economic efficiency than with addressing mounting social insecurities such as rising unemployment (Habermas 200I).

Meanwhile, by 1994, a series of popular campaigns against neoliberal policies had buffeted the North American publics in successive waves, from North to South. In Canada, widespread public opposition to the proposed CanadaUS Free Trade Agreement coalesced in 1988 into a cross-country anti-free trade movement (Ayres 1998). Canadian social activists and nationalists feared liberalizing trade with the U.S. would result in the exodus of jobs, pressure to harmonize social programs and the possible loss of cultural identity. The anti-free 
trade movement that emerged played a highly public and intrusive role in the Canadian federal election that autumn, which turned into a de facto referendum on the proposed accord. Despite the eventual ratification of the CUSFTA, due in no small part to the splintering of the anti-free trade opposition party vote in the federal election, the Canadian cross-country coalition-building campaign provided a useful model for U.S. and Mexican groups to adopt in the subsequent campaign against the NAFTA.

Anti-NAFTA mobilizing drew from both national-level campaigns as well as trilateral strategizing and protest actions mounted between Canadian, U.S. and Mexican civil society groups (Macdonald and Schwartz 2002). More specifically, while national groups may have had different mobilization agendas, there was an emergent trilateral collective action frame rooted in a distrust of NAFTA as a thinly veiled neoliberal document. Nationally, innovative new coalitions emerged, such as the Alliance for Responsible Trade (ART) and the Citizens Trade Campaign (CTC) in the U.S. (Dreiling 20oI), and the Mexican Action Network on Free Trade (RMALC) in Mexico, the latter notably modeling itself after the Canadian anti-free trade coalition (Sinclair 1992). NAFTA's eventual ratification, despite persistent public doubts and civil society organizing, ultimately would not be the end of popular discontent. The Zapatista guerrilla movement in the southern Mexican state of Chiapas, began its uprising on behalf of the majority poor indigenous people of Chiapas on January I, 1994, specifically targeting NAFTA and its neoliberal economic prescriptions for continentally liberalized trade and investment.

Meanwhile, as European and North American collective action frames, which focused on the perceived ills of liberalizing economies, buttressed these continental-level protest campaigns, state actors and civil society organizations across the developing South had been mounting their own protests for years against the social fallout caused by IMF structural adjustment programs, the repressive policies of brutal dictatorships or the generalized inequities of the post-World War Two Bretton Woods system. ${ }^{3}$ In the immediate post-war period through to the breakdown of the Bretton Woods system in the early I970s, many state actors frequently in partnership with business associations and non-governmental associations (NGOs), pursued state-led policies such as import substitution industrialization or cartels, in largely futile efforts to alter the international division of labor, improve the terms of trade, or improve developing states' positions

3. Certainly some would argue that people across the developing South have been resisting the economically dominating, colonialist and imperialist policies of the developed North for centuries. See Heckscher (2002) as well as Cavanagh (2002). relative to the global economy. The United Nation's sponsored New International Economic Order project also represented an attempt by state and civil society actors from the developing South to negotiate new and more favorable economic arrangements with the wealthier Northern industrialized states.

Yet, the oil shocks of the I970s and the emergence of the debt crisis in the early I980s largely shifted the locus of resistance in the developing South to civil society actors. As numerous states across Africa, Latin America and Asia sought to stave off fiscal insolvency, structural adjustment programs were arranged with the IMF, the negative repercussions of which almost always fell on the more vulnerable social actors. In exchange for desperately needed loans, the IMF prescribed deep budget cuts to social spending, a lowering of taxes, increases in interest rates and a general liberalization of trade and investment policies to encourage states across the South to become more hospitable to the arrival of multinational corporations and capital. Frequently lacking institutional allies within the affected polities or organizational resources, including independent labor unions, social actors often responded to these austerity programs with much less organized acts of resistance and protest, including food riots, strikes and other sometimes violent urban street actions (Walton and Ragin 1989; Acuna and Williams 1994; Walton and Seddon 1994). Those groups that did mount better organized grassroots responses to this so-called "shock therapy" also found themselves harassed if not shut down by the military dictatorships and authoritarian regimes which were frequently on the receiving end of IMF loans.

Thus, by the mid-I99os, a number of regional protest campaigns were being shaped by collective actions frames that implicated neoliberal policies and institutions for the mounting inequalities and dislocations of the post-Bretton Woods era. In fact, the record of neoliberalism around the world was less than auspicious and made it easier for activists to assign blame: the total external debt of developing countries had skyrocketed, the gap between the richest and poorest states had grown demonstrably, poverty had increased in many developing states, and the average per capita income growth rate was significantly lower across the developing south than had been the case in the roughly twenty years before the onset of the debt crisis and the policy generalization of the neoliberal model. ${ }^{4}$ Furthermore, the international economy had become increasingly unstable, buffeted by a number of financial shocks encouraged by unregulated capital flows. These shocks in Mexico, and then eventually East-Asia, Russia and Brazil, which

4. Evidence abounds of the uneven results of neoliberal globalization over the past two decades. These examples are drawn from the United Nations (1999) and the World Bank (2000). Also see Weller, Scott and Hersch (2001) and Stiglitz (2002). 
had evolved out of a globally deregulated market for currency speculation, would further blemish the neoliberal record. Even across portions of the developed North, especially in Western Europe, rising unemployment and the image of increasingly financially straightjacketed welfare systems provoked more widespread public unrest.

In conjunction with this at best uneven neoliberal record, an expanding array of international agreements, which codified neoliberal principles to promote and safeguard liberalized trade and investment, encouraged new expressions of social discontent. NAFTA, the EU Maastricht Treaty, and perhaps most notably, the creation of the WTO in 1995, raised concerns about the hierarchical and elitist structure of trade negotiations and institutions. Moreover, the WTO's new agenda also attracted concern, as in an effort to enforce a rules-based trading system, the institution turned its attention beyond such traditional protectionist devices as tariffs and quotas to a much broader and increasingly controversial array of state laws and regulations that could potentially now be interpreted as trade restrictive. Finally, in light of the WTO's new expanded mandate, attention focused on the lack of international safeguards for labor and human rights, environmental protection and other social concerns.

\section{Towards the Coalescing of a Master Frame Against Neoliberalism}

As these disparate collective action frames were shaping regional protests, several important trends were also working to more thoroughly discredit neoliberal policies and institutions, while at the same time legitimate a more widely shared critique of neoliberalism. As the neoliberal record received more widespread and vocal criticism, more space opened up for civil society networking, collective bargaining and political lobbying across a number of developing states, especially across Latin America and South-East Asia, where many states had made transitions to electoral democracies over the previous decade. At the same time, national civil society organizations from developing states were increasingly networking transnationally with organizations from the developed North at socalled countersummits as well as through the Internet. In particular, so-called "People's Summits," became venues for social activists to meet to share experiences, workshop, strategize and align their national diagnostic frames against the perceived inequities of neoliberal policies and institutions (Korzeniewicz and Smith 200I). These summits, and the increased availability of the Internet, set the stage for the crystallization of an increasingly transnationally-shared diagnostic master frame against neoliberalism.

People's Summits were held parallel to trade minister and heads-of-state gatherings negotiating the proposed Free Trade Area of the Americas (FTAA) in Chile, Brazil and Costa Rica. Similar-style summits were being held to coun-
Framing Collective Action Against Neoliberalism

ter the Asia Pacific Economic and Cooperation Forums (APEC) in Vancouver and Manila. One of the more notable counter gatherings took place in Paris in 1997 to strategize and share national perspectives on the proposed Multilateral Agreement on Investment (MAI). The anti-MAI strategy meetings attended by a coterie of civil society organizations helped to spearhead subsequent domestic and international campaigns against the MAI. The MAI negotiations ultimately collapsed when France pulled out, and credited its decision in part to what it referred to as a "global civil society" of anti-MAI activists. ${ }^{5}$

The explosive use of the Internet by thousands of NGOs would also in fact serve as a key means of bridging a variety of national and regional anti-neoliberal collective action frames. Through the use of listservs, email and web sites, international NGOs as varied as the International Forum on Globalization, the Third World Network, the Hemispheric Social Alliance and the Focus on the Global South, ${ }^{6}$ shared information and developed similar critiques of neoliberalism. Hundreds of more nationally-focused NGOs, which were either members of or linked to such larger international organizations, also shared information and critical perspectives gleaned from the Internet in more face-to-face grassroots settings. Hemispheric civil society groups crafted the Alternatives for the Americas text, ${ }^{7}$ a social-democratic and sustainable-developmental alternative to the proposed FTAA, during parallel People's Summits to the FTAA negotiations, and subsequently edited and revised it via Hemispheric Social Alliancemember Internet exchange (Ayres forthcoming).

Opponents of neoliberalism were also energized by U.S. Congressional opposition to the renewal of fast-trade authority. Fast-track power authorizes the U.S. President to negotiate trade accords with foreign countries, with Congress relegated to a reduced role of simply approving or rejecting the proposed accord. With every president since Richard Nixon in the I970s enjoying this privilege, U.S. President Clinton sought congressional renewal in 1997. However, Clinton withdrew the request in the face of a groundswell of opposition from both labor unions upset with his strong-arming of NAFTA through Congress in 1993, as

5. See http://www.finances.gouv.fr/pole ecofin/international/ami0998/ami0998. $\underline{\mathrm{htm}}$. For more on the role played by civil society groups and the Internet in opposing the MAI, see Smith and Smythe (1999) and Diebert (2000).

${ }^{6 .}$ See Steger (2002) for an excellent discussion of the role played by NGOs in countering neoliberal ideology, as well as a substantive index of NGO web sites.

7. To read the Alternatives for the Americas document, or to retrieve information on the Hemispheric Social Alliance, see http://web.net/comfront. 
well as opposition from grassroots lobbying efforts from the CTC and ART coalitions. The following year a reintroduced fast-track proposal went down to defeat, marking a significant trade policy victory for the growing number of civil society organizations across the U.S. who had shown increased skepticism of the supposed benefits of neoliberalism (Shoch 2000). The Clinton Administration's efforts to reframe the debate over fast-track, by renaming it "trade promotion authority," thereby putting a more benign spin to what was otherwise a tool to promote neoliberal policy proposals, had failed to win reauthorization.

In short, as the I990s came to a close, a master diagnostic frame critical of neoliberal globalization slowly crystallized and gained a wider international acceptance. It was not a completely hegemonic counter frame-regional and national-level variations persisted. Yet, the strength of this anti-neoliberal master frame lay in its breadth and capacity to absorb and accommodate the variety of movement and region specific frames that spurred collective action against neoliberal agreements and institutions over the previous several years. In fact, this master frame clearly took on a sufficiently broad interpretive scope in its inclusiveness, cultural reach and flexibility (Benford and Snow 2000) arguably to function as a master "injustice frame" (Carroll and Ratner 1996; Klandermans et al. 1999), indicting neoliberalism for a variety of perceived injustices: from environmental degradation, the shifting of jobs to low wages production sites, human rights abuses in sweatshops, and still growing poverty and persistent indebtedness across the developing world. Thus, on the eve of the autumn 1999 protests against the WTO millennial round in Seattle, the parameters of a more clearly transnational diagnostic master collective action frame that would help guide for nearly two years a burgeoning array of large and geographically-varied anti-neoliberal protests came into focus.

\section{Framing Mobilizations from Seattle to Genoa}

The WTO protests in Seattle certainly did not initiate organizing against neoliberalism, but because the protests took place in the United States, they represented an important milestone in such efforts. United States business and political officials in the Clinton Administration were some of the most vocal supporters of neoliberal policies. Clinton, in fact, risked political capital and alienated members of the Democratic labor-left constituency with his combative and ultimately successful push for NAFTA's ratification (Cohen 2000), as well as his failed efforts to secure fast-track renewal. The emergence of the WTO in 1995, again with the solid backing of U.S. officials, as well as the start of FTAA negotiations, cemented the U.S. as a leading proponent of expanding the neoliberal paradigm globally.

Yet, the tens of thousands strong protests, which disrupted the Seattle
Framing Collective Action Against Neoliberalism

WTO meetings, and contributed to the failure by WTO bureaucrats to establish a negotiating agenda, ${ }^{8}$ sent a signal of widening discontent both outside and within the U.S. over its official policy embrace of neoliberal principles. Moreover, the image of failure emanating out of Seattle raised some of the most significant questions to that date about the legitimacy of neoliberal policies. These Seattle protests were highly visible, drawing upon on eclectic repertoire of tactics (Smith 200I): weeks of strategic Internet usage prepared activists with intimate knowledge of Seattle's downtown layout and WTO delegate's schedules; cellphones aided activists as they spread out across the city engaging in traffic blockading affinity groups; black bloc anarchists resorted to property damage to highly visible corporate symbols of neoliberal success, such as Nike and Starbucks; while thousands of people participated in union rallies and marches.

Moreover, Seattle brought together a collection of diverse, international groups, ${ }^{9}$ whose protests were buttressed by the highly visible and now transnational master collective action frame against neoliberalism. Protestors decried the hierarchical, elitist and closed-door character of the WTO negotiations, and argued that WTO decisions aided and abetted "corporate rule" over popular sovereignty, and facilitated a global "race to the bottom," where corporations exploited conditions of liberalized trade and investment by constantly relocating production to areas with low wage costs and limited government enforcement of social or environmental regulations. There are in fact numerous examples of what could be considered attempts at both diagnostic and prognostic frame alignment processes in books activists produced and disseminated after Seattle (Danaher and Burbach 2000; Starr 2000; and Barlow and Clarke 200I). Beyond such books, Internet web sites, activist listservs and the Independent Media Center outlets established throughout the world after Seattle served crucial frame dissemination roles. These activities thus challenged the inevitability thesis of neoliberal globalization, stirred what would become a more widespread public debate about the supposed benefits of related policies, and put business and political elites on the sudden unexpected defensive against a newly aggressive master frame that challenged the underlying precepts of neoliberalism.

${ }^{8 .}$ While the protests played a dramatically disruptive role during the meetings, and publicized significantly the anti-neoliberal collective action frame, disagreements over trade policy between the European Union and the U.S. as well as between Northern and Southern states, contributed to the overall failure of the Seattle WTO Ministerial.

9. While a majority of the protestors who descended on Seattle were from the U.S. and Canada, (Almeida and Lichbach 200I), there was still a notable representation of international civil society groups among the demonstrators. 
After Seattle, the contest over what "globalization meant"-between the struggle to convince a wider set of domestic and international audiences of the supposed benefits or downsides of neoliberalism-grew intense. This is understandable, as the political context for framing processes frequently changes dramatically between early and more mature periods of collective action, especially after a "movement has established itself as a serious force for social change" (McAdam, McCarthy and Zald 1988: 17). Moreover, framing processes in a maturing movement are the "subject of intense contestation between collective actors representing the movement, the state, and any existing coutermovements" (Ibid: 16). That political and business elites around the world would react much differently to the anti-neoliberal protest movement following Seattle was then unsurprising.

In fact, a microcosm of the hotly contested framing debate emerged in the middle of the Seattle protests on the opinion pages of the New York Times. Following the first and most disruptive day of Seattle protests, Times' columnist Thomas Friedman wrote an essay entitled, "Senseless in Seattle," in which he decried the WTO protestors as "a Noah's ark of flat-earth advocates, protectionist trade unions and yuppies looking for their I960s fix" (Freidman 1999). Friedman, an ardent believer in the benefits, if not the inevitability of neoliberal globalization, as he argues in The Lexus and the Olive Tree (Friedman 2000), in effect repudiated the protestors' diagnostic collective action frame. He also contributed to what would become a major plank in the counter-response by supporters of neoliberalism, by characterizing protestors as "anti-globalization."

Naomi Klein, Canadian author of No Logo (Klein 2000), characterized as a "bible" for activists mobilizing against neoliberalism, met Friedman's charges the following day in her own Times' essay, entitled, "Rebels in Search of Rules" (Klein 1999). Here Klein refuted Freidman's critique, reiterating the concerns protestors had with neoliberal globalization and pointedly contesting the "antiglobalization" label. Protestors in Seattle were not against the globalization of economies, cultures and technologies, Klein argued, but against the current WTO-dominated rules-based system that focused mostly on promoting trade and investment liberalization, while remaining silent on consumer, labor, environmental or human rights concerns. What the protestors wanted, Klein argued, were rules for a global economic system that would consider such concerns and a new global institution that matched a focus for economic growth with considerations of the social and environmental consequences of trade and investment promotion. Interestingly, Klein was rearticulating the contours of the diagnostic frame against neoliberalism, while searching out possible parameters for a prognostic frame.
In fact, while the anti-neoliberal "injustice frame" performed reasonably well in crafting a transnationally shared diagnosis of neoliberalism's faults, movement activists were having more difficulty undertaking prognostic framing. That is, proposing and agreeing upon plans for attacking neoliberal policies and institutions, as well as in encouraging new movement recruits to literally take to the streets to oppose neoliberal policies, was proving to be a far more difficult task. For, out of Seattle emerged a variety of visions for challenging neoliberalism and for presenting an alternative model to neoliberal globalization. While some groups sought to "deratify" the existing neoliberal trade and investment arrangements, others sought to reform the WTO, giving it the mandate and enforcement mechanisms to address social and environmental concerns. While some sought to attack and quite literally destroy global capitalism, branding the protest movement "anti-capitalist," others sought a global "New Deal" to create a more socialdemocratic global system that included such protections as a global minimum wage. Yet, despite these divisions, over the course of the nineteen months from the Seattle protest to the much larger protests in July 2000 against the Group of Eight (G8) Summit in Genoa, Italy, the protest movement mobilized effectively and primarily on the strength of its well-received diagnostic master collective action frame, and was less hobbled by differences at this time over longer-term goals.

After Seattle, increasing numbers of people attended protests, which targeted neoliberal summits and institutions. Notable protest events occurred at: the IMF/World Bank meeting in Washington, DC, April 2000; meetings of the World Economic Forum in Melbourne, Australia, September 2000; IMF/World Bank meetings in Prague, Czech Republic, September 2000; the Asian-Development Bank meetings in Chiang Mai, Thailand, May 2000; the $3^{\text {rd }}$ Summit of the Americas FTAA meeting, Quebec City, Canada, April 200I; and the G8 summit, Genoa, Italy, July 200I. Notably, these large summit gatherings did not take place in a vacuum, but were accompanied by numerous parallel national protests across developed and developing states. However, the larger gatherings, especially the summit protests, alternative People's Summits, and the first World Social Forum, which met in Porto Allegre, Brazil in Winter 200I, served as critical diagnostic frame dissemination sites, publicizing, reinforcing and spreading transnationally tenets of the anti-neoliberal collective action frame. Frame alignment processes have been found to be most successful in collective settings (McAdam, McCarthy and Zald I988), where ideas and sentiments are shared and interpreted. And the proliferation of teach-ins, countersummits, street theater and dramaturgy proved crucial in transnationalizing the anti-neoliberal diagnostic frame. 
Figure 1 - Contested Interpretations of Globalization Processes

\begin{tabular}{|c|c|c|}
\hline Actors & Arguments/Claim & Policy Proposals \\
\hline \multicolumn{3}{|l|}{ anti-neoliberal protest movement } \\
\hline $\begin{array}{l}\text { + civil society activists } \\
\text { + national/transnational social } \\
\text { movement organizations } \\
\text { + Independent Media Centers } \\
\text { + Internet web sites }\end{array}$ & $\begin{array}{l}\text { + race to the bottom } \\
+ \text { democratic deficit } \\
+ \text { hierarchical } \\
+ \text { non-transparent } \\
+ \text { deliberate political } \\
\text { process } \\
+ \text { corporate rights }\end{array}$ & $\begin{array}{l}\text { + deratify } \\
+ \text { reform existing } \\
\text { treaties } \\
+ \text { debt relief } \\
+ \text { strengthen state } \\
\text { sovereignty } \\
\text { + deglobalize } \\
\text { + return to the local }\end{array}$ \\
\hline \multicolumn{3}{|c|}{ neoliberalism proponents (countermovement) } \\
\hline $\begin{array}{l}\text { + states } \\
+ \text { multi-national corporations } \\
+ \text { currency speculators } \\
+ \text { financial media outlets } \\
\text { + IMF/World Bank/WTO }\end{array}$ & $\begin{array}{l}\text { + there is no alternative } \\
+ \text { inevitable, desirable } \\
\text { process } \\
+ \text { irreversable } \\
+ \text { best prescription for } \\
\text { economic growth }\end{array}$ & $\begin{array}{l}\text { - liberalized trade } \\
\text { and investment } \\
\text { + deregulate } \\
\text { + cut taxes } \\
\text { + privatize } \\
\text { + reduce public } \\
\text { expenditures }\end{array}$ \\
\hline
\end{tabular}

On the eve of the Genoa, Italy $\mathrm{G} 8$ protest, then, politicians, business leaders and media outlets were paying increased attention to the concerns of the movement, as the "Washington Consensus" that had sustained the neoliberal globalization frame appeared to be cracking (Broad and Cavanaugh 1999; Useem 200I). Suddenly the World Bank was professing an interest in sustainable development projects, international institutions were becoming more open to NGO participation, politicians were entertaining thoughts of much more dramatic debt relief for impoverished states as well as taxes on global currency speculation, while debates over neoliberalism became much more common editorial page fare. At the same time, the anti-neoliberal protest movement appeared to have gained momentum, propelled by an eclectic set of protest repertoires combined with a general transnational consensus between civil society groups against the abuses of corporate power and corporate influence over popular democratic decisionmaking processes. Civil society groups and activists shared a strong sense of what they felt was "wrong" with neoliberalism; what remained unresolved was the development of collectively shared and agreed upon solutions and strategic responses to these problems.

\section{AFTER SEPTEMBER 11: THE ALTERED TERRAIN FOR ANTI- NEOLIBERAL PROTEST}

The terrorist attacks on the United States on September II, 20or had a dramatic and immediate effect on the mobilization potential for activism against neoliberal institutions. The fallout from the attacks exposed weaknesses in the anti-neoliberal collective frame, temporarily dampened enthusiasm, at least in the U.S., for large-scale contentious protest, and illustrated forcefully the continued relevance of the state in the structuring of movement activity. Over time, moreover, the limits especially of prognostic framing processes became apparent as activists struggled to develop coherent plans of action for challenging neoliberal policies and institutions. Figure I illustrates both the framing contest that had ensued, especially following the Seattle WTO protests, as well as the differences between interpretive beliefs germane to anti-neoliberal diagnostic and prognostic framing processes.

In fact, state authorities-particularly in the U.S. after September IIadopted a much more aggressive approach towards containing protests as well as in reasserting a multi-pronged neoliberal agenda. On the one hand, with the passage of such legislation as the USA Patriot Act, it became easier for U.S. government agencies to criminalize dissent-a tactical approach that had begun prior to September II (Stewart 200I; Scher 200I; della Porta and Tarrow 2002) - but one that gained greater legitimacy thereafter as authorities publicly equated protests against neoliberal globalization with terrorism (Panitch 2002). ${ }^{10}$ Thus, while protestors still rallied at the New York City meeting of the World Economic Forum in January 2002, the police presence was so extensive, and the aftershocks of September II still so fresh, that both the opportunities and the appetite for large contentious protests were missing. This pattern of maintaining a large police presence continued to thwart large-scale demonstrations, especially across North America. From the meeting of the Group of 8 leading industrialized states in Kanaskas, Alberta in summer 2002, to the following July WTO ministerial meeting in Montreal, Quebec, police curtailed demonstrations and kept activists off-balance with preemptive arrests and security perimeters (Thanh $\mathrm{Ha} 2003$ ).

10. In the immediate aftermath of the terrorist attacks Italian Prime Minister Sylvio Berlusconi mused on the "singular coincidence" between the terrorist attacks in the U.S. and the protests against neoliberal globalization, while U.S. Trade Representative Robert Zoellick in a speech in Washington D.C. hinted at what he felt were "intellectual connections" between terrorists and "others who have turned to violence to attack international finance, globalization and the United States." See Erlanger (200I) and Palast (200I). 
It was clear, moreover, that U.S. activists were on the defensive and hesitant about their tactical direction after September II, as large-scale raucous protests seemed out of step with the national mood. ${ }^{11}$ The state responses to both the terrorist attacks as well as to anti-neoliberal protest, posed a challenge to prognostic frame dissemination, as activists now had to engage in a public relations battle to de-link in the minds of an anxious U.S. public, protest against neoliberal policy from acts of terrorism. Moreover, growing anti-war activism-first as the U.S. invaded Afghanistan to overthrow the Taliban regime, and then once the Bush Administration quickly refocused for a possible war with Iraq-posed a challenge to sustaining an anti-neoliberal collective action frame. The energy devoted to straightening out the protest movement's identity and the meaning behind any new demonstrations was draining, as many protest groups struggled to reconcile being both opposed to neoliberal globalization and pro-peace (Huber and McCallum 2002).

At the same time, as activists across the U.S. worked to clarify their postSeptember II strategies for challenging neoliberalism, the Bush Administration embarked on a campaign to strategically reassert the neoliberal agenda. Only weeks after the terrorist attacks, President Bush told business leaders at the Shanghai meeting of the APEC forum, that terrorism could be defeated through the promotion of free trade, while U.S. Federal Reserve Chairman Greenspan argued that the attacks on the U.S. made it even more urgent that the WTO talks in Qatar succeed (Wayne 200I). The renewal of fast-track trade negotiating authority became a test of patriotism for waffling members of Congress (Sanger 200I), and by July 2002, Bush had won reauthorization of this power. Once equipped with this negotiating tool, the Bush administration would focus on aggressively advancing neoliberal policy goals through parallel tracks in the ongoing FTAA hemispheric discussions, as well as within the Doha, Qatar round. ${ }^{12}$

Beyond the challenges faced by activists in the U.S., regional and tactical differences within the protest movement against neoliberalism became much more apparent. Clearly, civil society groups during the late I99os had found it increasingly easier to develop shared and ultimately transnational understandings of the

11. See for example Carter and Barringer (200I); Wayne (200I); Fries, (2002); and Bygrave (2002).

12. Despite marginalizing protestors from the FTAA and WTO negotiating sessions, policy divisions especially between developing and developed states over agricultural subsidies in the developed North, increasingly threaten to derail both the regional and global neoliberal trade agenda. See Drohan (2003). experiences and problems fostered on different regions by neoliberal economic policies, than in devising mutually reconcilable strategic responses to these problems (Stuart 2003). Differences of opinion, illustrative of the limits of anti-neoliberal prognostic framing, starkly emerged in setting such as the World Social Forum (Cooper 2002; Faux 2003), over a variety of tactics and goals. Questions that confronted activists included: what are the more effective tactics for challenging neoliberal policies: more consultative and collaborative engagement in neoliberal summitry by NGOs, or grassroots mobilization and contentious protest $?^{13}$ Moreover, what are the appropriate and mutually acceptable goals for the movement: to reform the existing global capitalist system, or to deratify existing trade agreements? Should activsts work to strengthen state sovereignty or move beyond the state to "return to the local" in the pursuit of "deglobalization?"14

The persistent North-South divide, in terms of resource availability, organizational strength, and the underlying technological digital disparities, also challenged differently the capacity of regional civil society groups to continue to connect local grassroots concerns to transnational protest campaigns (Smith 2002). Such resource asymmetries have become apparent, for example, in the hemispheric mobilization against the FTAA. Civil society group divisions over tactics and resources have challenged the legitimacy of the Hemispheric Social Alliance as a broadly-based transnational social movement organization (Massicotte 2003), and revealed strategic splits between groups desiring an insider role in summit deliberations and those groups who view themselves as outsiders and supportive of large-scale civil disobedience against FTAA neoliberal summitry (Korzeniewicz and Smith 200I).

\section{CONCLUSION}

The mobilization of beliefs and interpretations critical of neoliberal globalization had been central to the eruption of a protest movement that achieved global proportions by 2003. Movement and region-specific collective action frames critical of the impact of neoliberal policy were shaped out of contentious struggles that preceded by well over a decade the eventual development of protests of larger scale and global scope. A master collective action frame rooted in

13. To sample such discussions see Klein (200I), Grundy and Howell (200I), Penniman (2002) and Smith and Korzeniewicz (2003).

14. For discussions of the different possible goals for the anti-neoliberal movement, see Narsalay (2002); Scholte (2002); Bello (2002); Laxer (2003). 
a diagnosis of neoliberalism's policy ills served as a broadly inclusive interpretative medium, targeting for blame neoliberal policies such as unfettered trade and investment and the rulings of institutions such as the WTO and the IMF. However, it was the very inclusiveness and accommodating character of this antineoliberal master frame-embracing in its diagnosis such varied concerns as the degradation of the environment, emerging democratic deficits and the decline of popular sovereignty, human rights abuses under sweatshop conditions, or even opposition to the U.S. war with Iraq or the rights of Palestinian refugees-which limited prognostic framing processes, exposing divisions within the international community of activists over proposed strategies for carrying out plans of action against neoliberalism.

Yet, despite the more challenging environment for prognostic framing, the fallout from the terrorist attacks on the United States has had an unanticipated effect: it has served to illustrate the durable character of the protest movement against neoliberalism. That is, the movement has evolved and prospered despite the constraints bearing down particularly on U.S. activists. Events since September II refute those claims by critics asserting that the movement was largely comprised of labor union protectionists from wealthy Northern states. Rather, the most significant and innovative protest events have continued outside North America. A transnational diagnostic frame critical of neoliberalism has remained a durable feature of demonstrations against neoliberal policies after September II, even if these protests have retained a national or regional flavor dependent especially on the availability of activists and organizations most closely at hand.

For example, the World Social Forum, held first in Brazil, and in 2004 in Mumbai, India, continues to draw greater numbers of people and represents a crucial forum for potentially developing a more widely accepted prognostic frame against neoliberalism. The European Social Forum held in Florence, Italy in November 2002, drew over one million people, the Asian Social Forum held in Hyderabad, India in January 2003 attracted 15,000 activists, while organizers across North America planned for a series of social forums in select cities throughout 2003 and into 2004. These regional social forums are rooted in the experiences of national civil society group opposed to neoliberal policy, but are tied together in the larger transnational diagnostic collective action frame that continues to express itself out of Porto Alegre with the slogan, "Another World Is Possible" (Bidwai 2003).

There continues to be as well numerous examples of regional and transnationally-coordinated contentious protests against neoliberal policy initiatives. Hundreds of protest events took place in cities around the world to coincide with the $4^{\text {th }}$ Ministerial meeting of the WTO in Doha, Qatar in November 200I. ${ }^{15}$ Regionally, anti-FTAA protests occurred in Quito, Ecuador in autumn 2002, against the $7^{\text {th }}$ Ministerial Meeting of the FTAA. These protests were backed by a variety of North and South American solidarity events, with the Quito protests specifically benefiting from North-South civil society collaboration (Ruben 2002) ${ }^{16}$ In September 2003, activists also undertook numerous global solidarity actions to complement the protests against the WTO meetings in Cancun, Mexico. In fact, prognostic hemispheric frame alignment against the FTAA seems to be increasingly rooted in a growing option for the use of more combative tactics, indicative of the degree of opposition that exists across this region to the possible implementation of a hemispheric neoliberal agreement.

Finally, it is clear that in the midst of this continued transnational activism, the state has not lost the capacity to control events within its boundaries, and it will continue to play an important role in structuring protest. The current economic crisis spreading across Latin America, captured in the Argentine meltdown and the rejection of neoliberal policy prescriptions by the tens-of-millions who elected the Brazilian Workers Party candidate, Luis Inacio Lula da Silva into the president's office, suggests that critically positioned states in the world economy may become vocal opponents of the expansion of neoliberal policy, with Brazil potentially the leading roadblock to the successful completion of FTAA negotiations. In short, the protest movement against neoliberalism may gain new momentum from states, which ultimately retain the greatest capacity to influence and reform those political processes that have produced over two decades of hotly contested neoliberal policy initiatives. Any success in developing widely shared prognostic frames against neoliberalism may in turn depend upon the concerted opposition of centrally placed states who may share with activist civil society organizations innovative ideas for reforming current neoliberal arrangements.
15. A chart of November 200I protests events worldwide against the Doha WTO round can be viewed at http://www.tradewatch.org.

16. For more on the events in Quito, see "Police Rebel and Anti-Free Trade Protests in Quito End on Positive Note." http://foodfirst.org/progs/global/trade/ quito2002/2002-11-01-update.php. 


\section{REFERENCES}

Acuna, Carlos and William Smith. 1994."The Political Economy of Structural Adjustment: The Logic of Support and Opposition to Neoliberal Reform," in William Smith, Carlos Acuna and Eduardo Gamarra, eds. Latin American Political Economy in the Age of Neoliberal Reform: Theoretical and Comparative Perspecives for the 1990s. Boulder, CO: Lynne Rienner.

Almeida, Paul and Mark Lichbach. 200I. "To the Internet, From the Internet: Sources of Data about Antiglobalization Protest." Unpublished Manuscript.

Ancelovici, Marcos. 2002. "Organizing Against Globalization: The Case of ATTAC in France." Politics and Society $30(3): 427-463$.

Ayres, Jeffrey. 1998. Defying Conventional Wisdom: Political Movements and Popular Contention Against North American Free Trade. Toronto: University of Toronto Press.

Ayres, Jeffrey. Forthcoming. "Transnational Activism in the Americas: the Internet and Innovations in the Repertoire of Contention." Research on Social Movements, Conflicts and Change.

Ayres, Jeffrey and Sidney Tarrow. 2002."The Shifting Grounds for Transnational Civic Activity," in After September 11: Perspectives from the Social Sciences. http://www.ssrc.org/sept11.

Barlow, Maude and Tony Clarke. 200I. Global Showdown: How the New Activists are Fighting Global Corporate Rule. Toronto: Stoddard.

Bello, Walden, 2002. "Battling Barbarism." Foreign Policy. 132 4I-42.

Benford, Robert and David Snow. 2000."Framing Processes and Social Movements: an Overview and Assessment." Annual Review of Sociology

Bidwai, Praful. (2003)."A Great Movement is Born." Canadian Dimension. http://www. canadiandimension.mb.ca/extra/d0117pb.htm.

Bourdieu, Pierre. 1998. Acts of Resistance: Against the Tyranny of the Market. New York, NY: the New Press.

Broad, Robin and John Cavanagh. 1999."The Death of the Washington Consensus?" World Policy Journal 16(3): 79-87.

Bygrave, Mike. 2002. "Where did all the Protestors go?" The Observer (UK), I4 July.

Carroll, William and R.S. Ratner. 1996."Master Framing and Cross-Movement Networking in Contemporary Social Movements." Sociological Quarterly (37): 60I-25.

Carter and Barringer. 200I. "In Patriotic Times, Dissent is Muted." The New York Times. 7 December.

Cavanagh, John. 2002. "The History of the Movement." Foreign Policy in Focus. http:// www.fpif.org/discussion/0201globalization/messages/4.html.

Clark, John. 2003. Worlds Apart: Civil Society and the Battle for Ethical Globalization. Bloomfield, CT: Kumarian Press.

Cohen, Edward. 200I. The Politics of Globalization in the United States. Washington, DC: Georgetown University Press.

Cooper, Marc. 2002. "From Protest to Politics: A Report from Porto Alegre." The Nation. II March: II-16.
Danaher, Kevin and Roger Burbach. 2000. Globalize This! The Battle Against the World Trade Organization and Corporate Rule. Monroe, ME: Common Courage Press.

della Porta, Donnatella, Hanspeter Kriesi and Dieter Rucht, eds. 1999. Social Movements in a Globalizing World. New York: St. Martin's Press.

della Porta, Donnatella and Sidney Tarrow. 2002. "After Genoa: the Anti-Global Movement, the Police and Transnational Politics." Items: Social Science Research Council.

Diebert, Ronald. 2000."International Plug'n Play? Citizen Activism, the Internet and Global Public Policy" International Studies Perspectives I: 255-272.

Dreiling, Michael. 200I. Solidarity and Contention: the Politics of Security and Sustainability in the NAFTA Conflict. New York, NY: Garland Publishing.

Drohan, Madelaine. 2003. "WTO Talks: We are Risking a Collapse," Toronto Globe and Mail 29 July.

Erlanger, Steve. 200I. "Italy's Premier Calls Western Civilization Superior to Islamic World." The New York Times. 27 September.

Faux, Jeff. 2003. "A Tale of Two Cities: Davos and Porto Alegre Square off on the Global Economy." The American Prospect. I4(2): 13-15.

Foster, John and Anita Anand. 1999. Whose World is it Anyway? Civil Society, the United Nations and the Multilateral Future. Ottawa, Canada: United Nations Association in Canada.

Friedman, Thomas. 1999. "Senseless in Seattle." The New York Times. I December.

Friedman, Thomas. 2000. The Lexis and the Olive Tree: Understanding Globalization. New York, NY: Anchor Books.

Fries, Jacob, 2002. "Anarchists Discover an Image Problem." The New York Times. 28 January.

Geyer, Robert and Jeffrey Ayres. 1995. "Rethinking Conventional Wisdom: Political Opposition Towards Integration in Canada and Denmark." Journal of Commonwealth and Comparative Politics. 3I(3): 377-99.

Grundy, John and Alison Howell. 200I. "Negotiating the Culture of Resistance: A Critical Assessment of Protest Politics," Studies in Political Economy 66: 121-132.

Habermas, Jurgen. 200I. "Why Europe Needs a New Constitution." New Left Review II: 5-26.

Heckscher, Zahara. 2002. "Long Before Seattle: Historical Resistance to Economic Globalization." Pp. 86-9I in Robin Broad ed. Global Backlash: Citizen Initiatives for a Just World Economy. Lanham, MD: Rowman and Littlefield.

Henderson, Hazel. 1999. Beyond Globalization: Shaping a Sustainable Global Economy. West Hartford, CT: Kumarian Press.

Huber, Emily and Jamie McCallum, "Anti-Globalization, Pro-Peace?" Mother Jones, I7 October 200I.

Khagram, Sanjeev, James V. Riker and Kathryn Sikkink, eds. 2002. Restructuring World Politics: Transnational Social Movements, Networks and Norms. Minneapolis, MN: University of Minnesota Press. 
Klandermans, Bert et al. 1999. "Injustice and Adversarial Frames in a Supranationa Political Context: Farmers' Protest in the Netherlands and Spain," pp. 134-47 in Donatella della Porta, Hanspeter Kriesi and Dieter Rucht, eds. 1999. Social Movements in a Globalizing World. New York: St. Martin's Press.

Klein, Naomi. 1999. "Rebels in Search of Rules." The New York Times. 2 December.

Klein, Naomi. 2000. No Logo: Taking Aim at the Brand Bullies. Picador.

Klein, Naomi. 200I. "Farewell to the End of History" Organization and Vision in AntiCorporate Movements," pp. I-I4 in Leo Panitch and Colin Leys, eds., Socialist Register 2002: A World of Contradictions. London: Merlin Press.

Korten, David. 1996. "The Failures of Bretton Woods," pp. 20-30 in Jerry Mander and Edward Goldsmith, eds., The Case Against the Global Economy: and For a Turn Toward the Local. San Francisco, CA: Sierra Club Books.

Korzeniewicz, Roberto and William Smith. 200I."Protest and Collaboration: Transnational Civil Society Networks and the Politics of Summitry and Free Trade in the Americas." Agenda Paper 5I. North-South Center. University of Miami.

Laxer, Gordon. 2003. “Stop Rejecting Sovereignty." Canadian Dimension. January/ February.

MacEwan, Arthur. 1999. Neo-Liberalism or Democracy? Economic Strategy, Markets, and Alternatives for the $21^{\text {st }}$ Century. New York, NY: Zed Books.

Massicotte, Marie-Josée. 2003. "Local Organizing and Global Struggles: CoalitionBuilding for Social Justice in the Americas." Pp. 105-125 in Gordon Laxer and Sandra Halperin (eds). Global Civil Society and Its Limits. Basinstoke, UK: Palgrave.

Macdonald, Laura and Mildred Schwartz. 2002. "Political Parties and NGOs in the Creation of New Trading Blocs in the Americas." International Political Science Review 23 (2): 135-158.

McAdam, Doug. John McCarthy and Mayer Zald. 1988. "Social Movements," in Neil Smelser ed. Handbook of Sociology. Newbury Park, CA: Sage: 695-738.

McAdam, Doug, John McCarthy and Mayer Zald, eds. 1996. Comparative Perspectives on Social Movements: Political Opportunities, Mobilizing Structures, and Cultural Framings. Cambridge: Cambridge University Press.

Narsalay, Raghav. 2002. "The State of the Anti-Globalization Movement: Challenges Ahead" Canada Watch 9(I-2): 57-64.

Palast, Greg. 200I. "Inside Corporate America." The Observer (UK). I4 October.

Panitch, Leo, 2002."Violence as a Tool of Order and Change: The War on Terrorism and the Antiglobalization Movement." Montbly Review. 54(2)ः I-23.

Penniman, Nick. 2002. "Where's the Movement?" The American Prospect. http://www. prospect.org/print/V13/18/penniman-n.html.

Prokosch, Mike and Laura Raymond. 2002. The Global Activist's Manual: Local Ways to Change the World. New York, NY: Thunder's Mouth Press.

Rodrik, Dani. 1997. Has Globalization Gone Too Far? Washington, DC: Institute for International Economics.
Ruben, Justin. 2002. “Trading Places: Protestors Rock FTAA Meetings in Quito." In These Times. http://www.inthesetimes.com/issue/27/01/news2.shtml.

Sanger, David. 200I. "Using the Battle of Terrorism for Victory on Trade." The New York Times. 28 October.

Scher, Amy. 200I. "The Crackdown on Dissent." The Nation. 5 Februaryः 23-26.

Scholte, Jan Aart. 2002. "The Future of Civil Society Opposition to Neoliberal Global Economic Governance." Canada Watch. 9(I-2): 59-64.

Shoch, James. 2000. "Contesting Globalization: Organized Labor, NAFTA, and the 1997 and 1998 Fast Track Fights." Politics and Society. 28(I): I19-150.

Sinclair, Jim. Ed. 1992. Crossing the Line: Canada and Free Trade with Mexico. Vancouver: New Star Books.

Smith, Jackie. 200I. "Globalizing Resistance: the Battle of Seattle and the Future of Social Movements." Mobilization. 6(I): I-20.

Smith, Jackie, 2002. "Bridging Global Divides? Strategic Framing and Solidarity inTransnational Social Movement Organizations." International Sociology. I7(4): $505-528$.

Smith, Jackie and Hank Johnston eds. 2002. Globalization and Resistance: Transnational Dimensions of Social Movements. Landham, MD: Rowman and Littlefield.

Smith, Jackie, Ron Pagnucco and Charles Chatfield eds. 1997. Transnational Social Movements and World Politics: Solidarity Beyond the State. Syracuse: Syracuse University Press.

Smith, Peter and Elizabeth Smythe. 1999. "Globalization, Citizenship and Technology: the MAI Meets the Internet." Canadian Foreign Policy 7(2): 83-105.

Smith, William and Roberto Korzeniewicz. 2003. "Transnational Social Movements, Elite Projects, and Collective Action from Below in the Americas. Forthcoming in Louise Fawcett and Moncia Serrano, eds. Regionalism's 'Third Wave' in the Americas. New York, NY: Routledge.

Snow, David and Robert Benford. 1988. "Ideology, Frame Resonance, and Participant Mobilization," pp. 197-217 in Bert Klandermans, Hanspeter Kriesi, and Sidney Tarrow, eds., From Structure to Action: Comparing Social Movement Research across Cultures. International Social Movement Research, vol. I. Greenwich, CT: JAI Press.

Snow, David and Robert Benford. 1992. "Master Frames and Cycles of Protest," pp. 13555 in Aldon Morris and Carol Mueller eds., Frontiers in Social Movement Theory. New Haven, CT: Yale University Press.

Snow, David et. al. 1986. "Frame Alignment Processes, Micromobilization, and Movement Participation." American Sociological Review. 5I*464-8I.

Starr, Amory. 2000. Naming the Enemy: Anti-Corporate Movements Confront Globalization. London and New York: Zed Books.

Steger, Manfred. 2002. Globalism: the New Market Ideology. Lanham, MD: Rowman and Littlefield.

Stewart, Lyle. 200I "Getting Spooked: the Anti-globalization Movement is Gaining Momentum, but Law Enforcers are Quickly Catching Up." This Magazine 34(5): 24-8. 
Stiglitz, Joseph. 2002. Globalization and Its Discontents. New York, NY: W.W. Norton and Co.

Stuart, Rieky. 2003. "Last Chance for an Agreement." Toronto Globe and Mail. 30 July. Tabb, William. 2003. "After Neoliberalism?" Montbly Review 55(2).

Tarrow, Sidney. 1998. Power in Movement: Social Movements and Contentious Politics, $2^{\text {nd }}$ Edition. Cambridge: Cambridge University Press.

Tarrow, Sidney. 200I. "Transnational Politics: Contention and Institutions in International Politics." Annual Review of Political Science 4: I-20.

Thanh Ha, Tu. 2003. "Police Round up WTO Protestors." Toronto Globe and Mail. 29 July.

United Nations. 1999. Human Development Report. New York, NY: United Nations.

Useem, Jerry. 200I. "Globalization: the New Future." Fortune. 26 November.

Walton, John and Charles Ragin. 1989."Debt, Protest and the State in Latin America," in Susan Eckstein ed. Power and Popular Protest. Berkeley, CA: University of California Press.

Walton, John and David Seddon. 1994. Free Markets and Food Riots: the Politics of Global Adjustment. Cambridge, MA: Blackwell.

Wayne, Leslie. 200I. "For Trade Protestors, Slower, Sadder Songs." The New York Times. 28 October.

Weller, Christian, Robert Scott and Adam Hersh. 20oI."The Unremarkable Record of Liberalized Trade." Washington, DC: Economic Policy Institute.

Welton, Neva and Linda Wolf. 200I. Global Uprising. Confronting the Tyrannies of the $21^{\text {st }}$ Century. Gabriola Island, Canada: New Society Publishers.

World Bank. 2000. Global Economic Prospects and the Developing Countries 2000. Washington, DC: World Bank. 